\title{
The Effectiveness of Implementing Internship in Making A Professional Notary in Jepara District
}

\author{
Muhammad Nur Aklif*), Aryani Witasari*) and Widhi Handoko**) \\ *) Student Master of Notary Law, Faculty of Law, Universitas Islam Sultan Agung \\ Semarang \\ $\left.{ }^{* *}\right)$ Lecturer Master of Notary Law, Faculty of Law, Universitas Islam Sultan Agung \\ Semarang \\ $\left.{ }^{* * *}\right)$ Lecturer Master of Notary Law, Faculty of Law, Universitas Islam Sultan Agung \\ Semarang
}

\begin{abstract}
The implementation of internships for Notaries is very important, however, in reality the awareness of the Notary candidates has not been carried out effectively, this is due to the practicality of prospective Notaries who want to practice immediately so that not infrequently, the internships are not carried out according to the time set by the existing regulations. The method in this writing is descriptive analytical. Based on the available data, it is found that in fact the effectiveness of the extension of the internship period is 12 (twelve) months to 24 (twenty four) months depending on the intention of the prospective notary who interned himself. Some notaries experience difficulties and experience confusion when opening an office even though they have undergone an internship period of 24 (twenty four) months. This is because they do not take advantage of time and do not undergo apprenticeship activities properly. The absence of an internship implementation guideline and the absence of programs that must be undertaken during the apprenticeship makes the effectiveness of the internships back to each prospective notary who interns. So can be said that the ineffective implementation of the Notary's apprenticeship has resulted in a lack of experience and at the same time resulted in a lack of quality of Notaries in carrying out their functions and duties in the community, especially in the Jepara Regency area.
\end{abstract}

Keywords: Effectiveness; Internship; Notary; Professional.

\section{INTRODUCTION}

One of the requirements to be appointed as Notary Public is having undergone an internship or actually working as a notary employee for at least 24 consecutive months at the office after graduating from strata two notary. This is as stipulated in Article 3 
letter "f" UUJN 2014, which confirms that they have undergone an apprenticeship or have actually worked as a Notary employee for at least 24 (twenty four) consecutive months at the Notary's office on their own initiative or on the recommendation of the Notary organization after graduating from strata two notaries. The purpose of the initiative itself in this case is that the prospective Notary Public can choose the office that he wants, but is obliged to obtain a recommendation from the Notary Office organization.

Based on the provisions in the article relating to internships, according to Alwesius there are 3 (three) things that must be fulfilled, namely: ${ }^{1}$

The term of the internship is 24 (twenty four) months, the period of the internship is calculated starting after a candidate for notary public has passed the strata two notary, the internship period must be carried out by a prospective notary "consecutively". These three conditions must be met before a prospective notary public can be said to have met the internship requirements as stipulated in the 2014 UUJN.

In contrast to the previous law, namely Act No. 30 of 2004 concerning the Position of Notary Public (hereinafter referred to as UUJN Year 2004), Article 3 letter "f" states that the internship period is at least 12 (twelve) consecutive months at the notary's office. Since the enactment of UUJN 2014, the apprenticeship period becomes 24 months after a prospective notary public has passed the bachelor degree of notary and the internship period must not be interrupted, it must be consecutive, for example:

Si A had an internship at notary X's office for 1.5 years from 2012 to 2013 . Then A worked in another place (another field) and then in 2014, A returned to his apprenticeship to continue the previous internship process at notary X's office for 1 year. If you look at the number, it is true that $A$ has met the requirements because he has had an apprenticeship period or worked in a notary office for 2.5 years. However, because it is not carried out consecutively, it does not meet the requirements stipulated in Article 3 UUJN of 2014. ${ }^{2}$

Along with the extension of the internship period to 24 (twenty four) months, when viewed from the provisions of Article 88 UUJN 2014, which confirms that:

\footnotetext{
${ }^{1}$ Alwesius, Beberapa Catatan terhadap UUJN yang Baru, dalam http://alwesius.blogspot.com/2014/01/beberapa-catatan-terhadap-uujn-yang-baru.html, p.1 accessed on1 March 2015

${ }^{2}$ Ibid, p. 2
} 
a. Submissions as a Notary that are being processed, are still being processed based on Act No. 30 of 2004 concerning the Position of Notary Public.

b. The period of apprenticeship that has been undertaken by a prospective notary public is still calculated based on the requirements stipulated in this Law (amendment results).

Based on the provisions of Article 88 UUJN of 2014 mentioned above, it is clear that the process of appointing a notary that has been submitted prior to the enactment of the amendment to the Notary Position Law is still processed based on the old provisions (UUJN of 2004) but specifically for the apprenticeship period, the apprenticeship period that has stipulated in Article 3 letter "f" UUJN 2014, which is 24 (twenty four) months after the prospective notary graduated from strata two notary, without any exceptions. After the enactment of the amendments to the UUJN of 2014, all appointment processes that have not been issued a Decree of appointment as Notary Public on the effective date of the amendment to the Law on Notary Office, must meet the requirements for an internship period of 24 (twenty four) months.

Basically, it is not only a matter of internship time which is a benchmark or parameter that can be used as a reference that a prospective Notary Public is considered capable of becoming a professional Notary Public, but it depends on how a prospective notary is able to absorb the knowledge or knowledge that he / she gets during the internship process. In addition to the availability of knowledge and information in the internship place, at least the Notary who is used as an internship reference is able to provide new experiences for prospective notaries, because the Notary at the internship must have sufficient experience so that he is considered to have more useful abilities for prospective notaries.

Notaries in carrying out their duties to serve the interests of the community, should maintain their dignity and dignity. Tan Thong Kie stated that there is a habit among notaries who no longer read the deed so that the deed becomes an underhand deed. While in the deed he wrote that the deed had been read by me, the notary, even though he had not read it. Winanto Wiryomartani, who at that time was a member of the Central Supervisory Council stated that notary supervision is basically to protect the community. According to Winanto Wiryomartani, a notary is a public official to serve the community, so in order to make an authentic deed by a notary, the public must be 
protected. For this reason, a Supervisory Council was formed whose function is to protect the public in the event of a legal violation by a Notary.

Based on this phenomenon, the notary organization, namely the Indonesian Notary Association (INI), proposes to conduct a joint apprenticeship which must be followed by prospective notaries other than internships at the office on their own initiative. ${ }^{3}$ The holding of this joint apprenticeship is not only aimed at producing ready-to-use and professional notaries but also to improve mastery, expertise and skills in carrying out notary duties and increase understanding of the notary's Code of Ethics and its application.

The urgency, the extension of the apprenticeship period for prospective notaries to 24 (twenty four) months is the spirit of the Indonesian Notary Association (INI), namely:

"First, to prepare ready-to-use prospective notaries; second, to improve the quality of notaries in Indonesia by printing reliable prospective notaries. Third, in order to obtain quality notaries who can be trusted by the public, because there is a difference between education in notary master's degrees and needs in practice to improve mastery, expertise, and skills in the implementation of the duties of a notary public and improve understanding of the notary's Code of Ethics and its application. "4

INI's central board in a plenary meeting held on 28 March 2014, stated that:

"The procedure for apprenticeship can be done twice a month. The time allocation is 24 consecutive months after graduating from the notary program. The planned joint apprenticeship curriculum includes a deepening of the Notary Position Regulations, Family Law, Code of Ethics 1, Deed Making Techniques. Another theory that needs to be explored is the deepening of property law, land law and techniques for making land deeds and banking. In addition, it also learned about Bankruptcy Law and Money Laundering Criminal Law. Participants in this joint apprenticeship will not only be applied to future notary candidates, but also prospective notaries who have undergone an internship, but are still not yet 2 years old; prospective notary who has worked as a notary employee but is not even 2 years old. ${ }^{5}$

A research in the form of a thesis was carried out by Siswanto Sunarto (2007) on the role of professional code of ethics in the promotion of notary office, where one of the results is: the provision of apprenticeship for notary official candidates, is only carried out formally, even though internships can actually improve the skills of prospective notary officials. . This is also supported by the results of research conducted by

${ }^{3}$ Hukum Online.com, Calon Notaris Wajib Magang Bersama, dalam http://www.hukumonline.com/berita/baca/calon-notaris-wajib-magang-bersama, accessed on 28 March 2015, p. 5

${ }^{4}$ LoC. cit

${ }^{5}$ Ibid. p. 5-6 
Nawang Andi Kusuma (2011) that there is no apprenticeship curriculum guideline for prospective notaries, so there is no uniformity between one notary and another in conducting apprenticeship coaching. As a result, the practice of referencing apprenticeship certificates is only a formality,

Regulation of the Association of Indonesian Notary Public Number: 19 / PERKUM / INI

/ 2019 concerning Internships, it is said that the objectives of the internship are:

1. Increase mastery, expertise and skills in carrying out the duties of a Notary public and in understanding the laws and regulations as well as legal theories relating to and / or related to the implementation of the notary's duties to prospective notaries, so that when appointed they can become qualified and ready Notary Public serve the interests of society.

2. Improve understanding of the Notary Code of Ethics and its application, both in the context of carrying out the position of Notary Public and in daily life.

3. Make prospective Notary Public about the importance of implementing an apprenticeship which is a practical education in order to carry out the position of a Notary publicly and correctly.

4. Giving confidence to prospective Notaries so that they are ready to carry out their positions properly.

5. Increase public confidence that prospective notaries are ready to carry out the position of notary as expected.

The internships described above are internships at the notary's office, while the internships that prospective notaries must go through are not only in the notary office but also joint internships. Joint internships can be carried out by ALB INI members if they have been interning at a notary office for at least 6 months. The time required to take part in a joint internship is 4 semesters. As explained in Article 7 of the Regulation of the Indonesian Notary Association Number: 10 / PERKUM / INI / 2018 concerning Amendments to the Regulation of the Indonesian Notary Association Number: 06 / PERKUM / INI / 2017 concerning Internships. This joint apprenticeship will not only be applied to future notary candidates, but also prospective notaries who have undergone an internship, but are still not even two years old, prospective notaries who have worked as notary employees, but also not even two years, as well as prospective notaries who will work as notary employees, but the work period will exceed two years. Especially for prospective notaries who will be beyond the two years, the notary who receives the apprenticeship must notify the regional management at his / her domicile regarding the start date of the prospective notary public and the prospective notary public is obliged to take part in the joint apprenticeship program. Internships with ALB INI members are a series of activities to improve mastery, expertise, and skills and the implementation of notary duties and increase understanding of the notary's code of 
ethics and its application. We have found many discussions about notaries in various forms such as thesis. Based on the background of the problems that have been stated, it is interesting to do a deeper study related to "The Effectiveness of Implementing Internships in Realizing Professional Notaries in Jepara Regency". This writing aims to analyze and describe related effectiveness of the implementation of internships in realizing professional Notaries in Jepara Regency.

\section{RESEARCH METHODS}

The method used is descriptive analytical method namely a research method to provide an overview of a situation or event and to explain the relationship between the incident and the problem to be studied. ${ }^{6}$ The results of this study are expected to provide a clear picture of the readiness of prospective notaries to open an office and practice being a notary after undergoing an internship at a notary's office for 24 (twenty four) months.

\section{RESULT AND DISCUSSION}

\subsection{Implementation of Current Notary Apprenticeship Policies in Jepara Regency}

Based on the Decree of the Directorate General of Higher Education, DEPDIKNAS RI No. 80 / DIKTI / KEP / 2000, the Notariat Specialization Program was officially changed to the Notary Masters Study Program, which in several ways experienced changes in the form of a reduction or addition of courses. It seems that the replacement of the Notary Specialist program still does not meet the expectations of the community because the Notary Specialist program does not seem much different from the old Notariat Specialization Program. ${ }^{7}$ Almost every Notary Master student hopes that after graduating they will immediately open a practice to become a Notary. Meanwhile, adequate provisions are needed considering that the responsibility after becoming a Notary is the responsibility of each individual. During his education in Master of Notary, lectures are a form of interaction between lecturers, students and knowledge / skills.

Understanding and perceptions of these three factors will determine the success of the teaching and learning process. Lecture is an activity that distinguishes between formal

${ }^{6}$ Nazir, Mohammad. (1993). Metode Penelitian, Jakarta: Ghalia Indonesia, p. 64

7Untung, Budi. (200 1). Visi Global Notaris, Yogyakarta: Penerbit Andip. 59 
and non-formal education. However, with regard to one's readiness to become a notary, lectures are not the only source of knowledge and not the only learning activity. Based on Article 3 of UUJN of 2004, there are several conditions that must be met in order to be appointed as a Notary, as follows:

a. Indonesian citizens;

b. Be obedient to God Almighty;

c. Be at least 27 (twenty seven) years old;

d. Physically and mentally healthy;

e. Has a law degree and graduated with a bachelor's degree in notary;

f. Have undergone an apprenticeship or have actually worked as a notary employee for 12 (twelve) consecutive months at the Notary's office on their own initiative or on a recommendation from the Notary Organization after graduating from keno strata twodance; and

g. Not having the status of a civil servant, state official, advocate, or not currently holding another position which is prohibited by law from concurrently serving as a Notary.

In UUJN 2014, there was a change in the notary's apprenticeship period, from 12 (twelve) months to 24 (twenty four) months. The extension of the apprenticeship period from 1 (one) year to 2 (two) years is actually not too heavy compared to the apprenticeship period stipulated in the Netherlands, where the apprenticeship period for Notaries is getting longer. After the release of the 1999 Notary Public, the apprenticeship period for prospective notaries became 6 (six) years.

So far, the laws and regulations in Indonesia refer to the Netherlands, so the articles in Stbl. 1860 No. 3 is a copy of the articles in the Notary Public in the Netherlands. However, in Stbl 1860 No. 3 there is no article that requires a "period of apprenticeship" (werkstage). In fact, in the Notary Public itself there is a provision that one of the conditions to be appointed as a Notary, the person concerned must be able to submit evidence that he has worked (uninterrupted) at one of the Notary offices for at least three years. At that time, the issue of apprenticeship in Indonesia was issued 
Ordinance 1907 No.485 which regulates the Notary Examination for parts I, II and III. This Ordinance does not explicitly include rules regarding the terms of apprenticeship. In the past there was also one Bijblad no. 5142 which alludes to an internship. The form is only in the form of a recommendation, namely from Gouvernementsmissive dated November 29, 1889 No.2763 to the Director van Justitie, so that if he receives a proposal to fill a Notary's vacancy, pay attention to the skills of the applicant including practical skills. "Internship period" is still considered as a condition for the appointment of a notary public, not as something urgent or urgent. Previously, the "internship period" requirement was not included directly, but became a formal requirement by attaching a notification letter from the Notary that had attended an internship at the Notary's office for two consecutive years after graduating from Notary Specialist or Master of Notary education approved by the organization.

A person who passes the Notary Master program must immediately do an internship to get an internship certificate as one of the conditions for registering to become a Notary. The procedure for the implementation of the previous internship, the first time by making an internship certificate signed by the Notary where the internship is addressed to the Secretary of the INI Regional Management in their respective places This application for an apprenticeship certificate is intended so that the secretary of the Regional Management of INI can be registered, since when he has started doing the apprenticeship so that when the 24 (twenty four) months of the internship has been completed, a certificate can be issued by the INI Regional Management based on the previously received internship certificate. as disclosed by the notary in Jepara Regency as follows:

At that time, a Notary who received a Notary candidate who was apprenticed, was told to make an apprenticeship application first, then on the basis of that apprenticeship application a certificate of apprenticeship registration was made to the local government. So the internship time is calculated based on the date when the internship starts. ${ }^{8}$

Judging from the juridical side, after UUJN, apprenticeship for notary candidates became very urgent because it became a necessity (dwingenrecth). However, because UUJN itself is addressed to Notaries, it does not rule out manipulation in the issuance

${ }^{8}$ Siti Ammanah, Interview, Notary in Jepara Regency, January 12, 2021 
of apprenticeship certificates by certain groups of Notaries. This is as expressed by the notary of Jepara regency that "internships are a necessity for prospective notaries. If the prospective notary public doesn't have enough experience yet, well.... Should be run according to the correct rules "9

In several universities that administer the Notary Master program, there are extra noncurricular activities such as internships ranging from 3-6 months. However, this is not sufficient as a provision for direct notary practice, because students at the same time make a final project (thesis), so that it is ensured that the quality of their internships is not optimal. It is different from those who have passed MKn and done an apprenticeship with totality, because there will be intellectual, mental, emotional and spiritual schooling in facing realities in the field.

It's just that until the research was carried out, according to the researcher, there was no similarity between the notaries in treating the apprentice either in the form of unwritten or written rules such as internship requirements. How to treat apprentices to prospective notaries are all still left to the respective notary recipients. Even though, based on the UUJN (Article 16 paragraph (1) letter $m$, it has been stipulated that accepting apprentices is one of the obligations of the Notary Public. In fact, it is not uncommon to find Notaries who have opened them. an older office that refuses to have his office used as an apprenticeship by prospective notaries. This is as stated by a Notary in Jepara Regency before becoming a notary who lived in the city of Purwodadi and had difficulty finding an internship as follows: . There are reasons for the seniors to reject those of us who want to do internships. In fact, even if asked to pay, I also want to. Finally I was forced to find an internship in the city of Jepara." 10

There is even a Notary in Jepara Regency who really found it difficult to find an internship when he had not opened an office before, as stated as follows:

I already feel the difficulty of finding an internship looking here and there rejected. He said the place was full, there was no place, just various reasons. So, if there are kids who want to do an internship, please go to my place, my door is wide open for those who want to do internship in my office. ${ }^{11}$

9Mulung Estu Prakoso, Interview, Notary in Jepara Regency, September 19, 2018

10 Mulung Estu Prakoso, Interview, Notary in Jepara Regency, January 11, 2021

${ }^{11}$ Debby Ekowati, Interview, Notary in Jepara Regency, January 13, 2021 
Notary is a legal profession and thus the Notary profession is a noble profession (nobile officium). It is called a nobile officium because the notary profession is very closely related to humanity. Deeds made by a notary can serve as a legal basis for the status of a person's property, rights and obligations. Errors in a notary deed can result in the loss of one's rights or the burden of someone on an obligation. An error occurs due to the notary's lack of understanding of the wishes of the parties, which is due to the lack of knowledge obtained if the apprenticeship is not carried out optimally.

In connection with the implementation of article 6 paragraph 2 of Association Regulation No.10 / perkum / INI / 2018, a Notary who receives an internship must meet 8 (eight) provisions, including:

1. Notary who receives an apprenticeship for at least 5 (five) years of work and is active in carrying out his position as a Notary with a number of deeds of at least 20 deeds per month.

2. Active in organizations or there is concern for the organization.

3. The capacity of the apprentice notary public is possible.

4. It is decided by the Regional Management on the recommendation of the Regional Management after getting the consideration of the Regional Honorary Council and the Regional Honorary Council, the Regional Supervisory Council and the Regional Supervisory Council (from the Notary element).

5. Provide reports to pengda about the start and end of the internship.

6. Gives the opportunity to prospective Notaries who are apprentices to take part in an apprenticeship program that is held jointly by the regional government and / or regional government.

7. Always pay attention to and comply with the laws and regulations regarding the Position of Notary Public and the apprenticeship program prepared and stipulated by the INI association.

8. Providing an opportunity to a prospective Notary who is apprenticed to become a Substitute Notary Public, if the person concerned has met the requirements.

Notary who receives an internship based on the Association Regulation is expected to have a moral responsibility towards prospective Notaries who are apprenticed in their place and it is hoped that during the 2 years of apprenticeship at the Notary's office, they can master the material according to the curriculum and syllabus semester 1 to 
semester 4 according to INI so that they are not impressed only to provide apprenticeship recommendation letter, but can understand the material. The desire of the organization to produce reliable notaries is increasingly shown by the assessment of prospective notaries. The organization does not want candidates for Notary Public to only carry out an apprenticeship at the Notary's office or a joint apprenticeship in mere formality. For this reason, the organization proposes an evaluation of the apprentices. The assessment will be carried out by the Notary who received the apprenticeship and the regional or regional administrator. The results of this assessment will be conveyed to the apprentices. If there are candidates for Notary Public who still do not meet the minimum passing standards, it is necessary to make improvements to the parts that are considered inadequate or incomplete.

\subsection{Implementation of Notary Apprenticeship Policies That Are Able To Realize Professional Notaries In The Future}

Some of the things to be achieved by adding an additional internship period for prospective Notaries include:

\section{a. Ability for ethical sensibility}

Ethical sensibility It can be seen from the ability of legal professionals to determine aspects of situations and conditions that have ethical importance.

\section{b. Ability to think critically (ethical reasoning)}

Ethical reasoningnamely the ability to think ethically and rationally regarding matters that are closely related to the tools and frameworks which are considered to be the entire legal profession ethics education. This requires the following approaches:

1) Using an objective perspective (impartial perspective). Objective means staking the problem fundamentally. The analysis is carried out objectively by eliminating subjective elements. This objective view can be done by placing oneself in a position as a person who is in justice so that he does not take sides. Objective also means leaving collegial ties including nepotism, collusion and corruption.

2) Improve the principles of action to a general and universal level. Professionals must be able to put down the principles which are the basic values of the problems 
faced. These general principles are for example the values of justice (legality), fairness (equity) and equality (equality).

3) Taking into account and considering the rights and welfare of several parties who are influenced by professional legal decisions based on the rights base on truth. Truth becomes the main foundation in solving the problems faced and equality is based on the basis of equal rights and responsibilities.

\section{c. Ability to act ethically (ethical conduct)}

Ethical conduct meant to be a manifestation of a sincere heart. This will be demonstrated by the behavior that is carried out in making decisions ethically and correctly. Ethical failure occurs because the guilty person does not have the courage to admit his mistake honestly. This may be because the person concerned is afraid of his future prospects.

\section{d. Ability for ethical leadership}

Ethical Leadership is the ability to conduct leadership ethically, which of course has to do with sincerity. In accordance with Article 15 paragraph (1) UUJN Year 2014, that notaries are authorized to make authentic deeds regarding all actions, agreements, and stipulations required by laws and regulations and / or those that are desired by those concerned to be stated in authentic deeds, guaranteeing certainty of dates. making deeds, keeping deeds, giving grosse, copies and excerpts of deeds, all of this as long as the deed is not also assigned or excluded to other officials or other people stipulated by law.

At first glance it looks simple, which is only making an authentic deed. However, the products produced by notaries have the power as perfect evidence. For this reason, in producing a product that will serve as evidence, special skills and skills are needed that are not only obtained in college, but have also been practiced in the daily work of a notary and this can be done when a candidate The notary is at the place of apprenticeship. The notary's responsibility in relation to the legal profession in carrying out his position cannot be separated from the law, so it is hoped that the notary can act to reflect on his service to the community. 
The notary profession is a profession that many people hope for. After completing the Master of Notary program, the thing that must be undertaken immediately is an internship for 24 (twenty four) months. Of course, senior notaries have a role in forming new notaries so that later they can be more professional in carrying out their duties. However, not all Masters of Notary graduates easily get internships. The average notary who is willing to accept an internship, sees that the prospective notary is a graduate of the same university or not a notary who is willing to accept an internship. ${ }^{12}$

The term apprenticeship is only a requirement so that prospective notaries know for a fact about notary practice and the ins and outs of the notary world. The notary will work independently, therefore to mentally prepare the prospective notary in dealing with tappers and various problems raised by the tappers, an internship process is required. Based on experience and cases that have occurred in which the prospective notary public will receive provisions when practicing to become a notary public later.

One of the requirements to become a notary is obliged to undergo an internship as follows: "have undergone an internship or have actually worked as a notary employee within 24 (twenty four) consecutive months at the notary office on one's own initiative or on the recommendation of the Notary Organization after passed the second degree notary. "

Based on the requirements mentioned above, according to the research results it is necessary to conduct a more in-depth study of the phrase "have undergone an internship or have actually worked as a notary employee ....". The 24 (twenty four) month apprenticeship period must be carried out correctly by the Notary candidates because so far it is not uncommon to find a prospective Notary who takes internship on Saturdays only, because during Monday to Friday the prospective Notary Public is still bound by work. in another office. Of course, this does not guarantee that the prospective notary will really absorb the knowledge gained during the internship, especially since the notary office is usually only open half a day on Saturdays.

\footnotetext{
${ }^{12}$ Notary Z, office in Jepara
} 
I'm a bit sorry that I didn't do the internship properly. I only signed in once a week and that was Saturday, even though I should have learned more if I attended an internship every day. The result is like this.... Confused when I started to open an office... .. "13

This issue should be of mutual concern, both from the Notary community, the organization of the Indonesian Notary Association and the government through the Ministry of Law and Human Rights because Notaries are public officials as an extension of the $i$ the hands of the state in preparing the authentic deeds needed by the community. Talking about apprenticeship in the notary's office and joint apprenticeship is felt by the author to be very necessary given the very heavy responsibility of the Notary, and it is borne individually by each Notary.

In addition to the internship period of 24 (twenty four) months plus joint apprenticeship, it is also necessary to regulate the timing of the internship itself, whether it must be done routinely every day from Monday to Saturday for 40 hours every week. This is because the purpose of the apprenticeship is so that prospective notaries really get experience from Notaries who have opened offices so that when later prospective Notaries are really ready when opening their own offices, they are able to practice properly and correctly, according to what has been seen on what the Notary does at his place of doing an apprenticeship.

Notary is a position that many people expect, especially for someone who studies the Notary study program. After completing the Notary Master Study program, the thing that must be undertaken immediately for prospective notaries is an internship for 24 (twenty four) months at the notary's office and balanced with joint apprenticeship activities.

The position of a notary is held or its presence is desired by legal regulations with the intention of helping and serving people who need authentic written evidence regarding conditions, events or legal actions. ${ }^{14}$ The position of a notary as a functionary in society is still felt to be respected, a notary is usually considered an official where someone

\footnotetext{
${ }^{13}$ Notary B who has opened an office in Pati Regency

${ }^{14}$ Habib Adjie, Op.Cit, p. 14
} 
can get reliable advice, everything he writes and determines is correct, he is a strong document maker in a legal process. ${ }^{15}$

Notaries work independently (independently), meaning that they are not dependent on their superiors or anyone else in carrying out their duties and positions. A notary must be able to decide for himself what deed and what legal formula is appropriate and be able to provide legal advice to the parties. In this regard, apprenticeship is indispensable for a prospective notary public, this is for the notary's own interests.

Many notaries who are not ready to carry out their functions after they have graduated from the Master of Notary study program when they open their own offices. Through the apprenticeship, prospective notaries are expected to know a lot of the ins and outs of notary practice in real terms, know the legal formulas that are most appropriate to use in making their act, both authentic and underhand, and regarding notary administration. This is because there are no standards that must be done during the internship, so there are no rules regarding what to learn while at the internship.

A notary who has opened an office for a long time certainly has a role in the formation of new notaries so that later the prospective Notary Public can be more professional and moral in carrying out his position as a Notary. However, not all Notaries provide discretion when carrying out internships. This is as stated in Article 3 letter $f$ of UUJN of 2014 which confirms that one of the requirements to be appointed as a notary is that the prospective notary has undergone an internship or has actually worked as a notary employee within 24 (twenty four) consecutive months participate in the notary office on their own initiative or on recommendation

Notary organizations after graduating from Strata Two Notary and in the explanation of Article 3 letter $f$ UUJN 2014 it is emphasized that what is meant by self-initiative is that prospective notaries can choose the desired office by themselves while still receiving recommendations from the Indonesian Notary Association (INI). Apprenticeship requirements for prospective notaries are imperative, meaning that they must be taken and there must be proof of evidence. ${ }^{16}$ Evidence that the Notary Candidate has indeed participated in an internship for 24 (twenty four) consecutive months at the notary's

\footnotetext{
${ }^{15}$ Thong Kie, Tan. (2007). Studi Notariat dan Serba-serbi Praktik Notaris, Cetakan Pertama, Jakarta, PT. Ichtiar Baru van Hoeve, p. 444

${ }^{16} \mathrm{Habib}$ Adjie, op.cit. p. 63
} 
office. This internship is very important for Notary Candidates, to align the notary knowledge obtained in college with notary practice, and other things that are not obtained in college but will only be obtained in notary practice. For example, administering the minutas of deeds into the repertorium or filling out a list book for letters that are booked or letters that are legalized, and more importantly learning to understand the wishes of the parties and formulating them in the form of a Notary Deed. In fact, not all notaries allow prospective notary apprentices to read the minimum deeds. In order to realize the effectiveness of the implementation of compulsory internships, then reconciliation should be carried out between the tertiary institutions that hold the Notary Masters program, the organization of the Indonesian Notary Association (INI) and the Ministry of Law and Human Rights. The issue of apprenticeship for prospective notaries should not be underestimated, because it is through the apprenticeship process that notaries who are ready to serve the public properly and correctly are formed.

So far, the implementation of apprenticeship for notary candidates in Indonesia, the requirements for prospective Notaries to participate in joint apprenticeship activities must meet the following criteria:

1. Has been registered as ALB INI (has ALB INI Number);

2. Has undergone an Apprenticeship at the Notary Public Apprentice Office for at least 6 (six) months as evidenced by an Apprenticeship Certificate from the Notary concerned;

3. Registering for the Joint Apprenticeship with the Regional Management of the Joint Internship organizer;

4. Include a Joint Apprenticeship Cover Letter from the Notary Recipient of the Apprenticeship, attaching an SKM from the Notary Recipient of the Apprenticeship;

5. Participate in the Joint Apprenticeship according to the schedule set by the Regional Management who organizes the Joint Apprenticeship.

The joint apprenticeship held by the Regional Board of the Indonesian Notary Public Association is an effort to increase the competence of a notary to become a professional Notary, because in the joint apprenticeship, it always discusses how notaries practice in making a deed as it has been adjusted to the regulations, and in 
accordance with the code of ethics. Before the joint apprenticeship was held, the apprenticeship for prospective Notaries was only an internship at the Notary's office.

The association makes a rule to hold a joint apprenticeship because it is deemed necessary, in order to support a profession full of responsibilities. Previously, before the reform era, to become a Notary Public you could apply for a SK (Letter of Decree) after graduating from the notary program for two years. This means that if a prospective notary graduated from the notary program, he / she cannot immediately apply for a decree, but must wait for two years after graduating. Therefore, an idea arose from the Indonesian Notary Association regarding what activities could be carried out to fill the two-year period for prospective Notaries, so that at that time the Central Board of the Indonesian Notary Public Association made an idea to state that prospective notaries must do an internship at notary office. After 2004, the apprenticeship was clearly regulated and contained in the UUJN 2004. After the reform was changed one year before graduating from the notary program in terms of being in college and one year after graduating from the notary program. In the 1999 era, apprenticeship was only undertaken for 1 (one) year after graduating, but in reality it was the same, namely one year of apprenticeship before graduating from the notary program and one year after graduating from the notary program. So it is actually the same as two years of apprenticeship, the only difference is the time it is carried out if the number of internships is long. internships are only undertaken for 1 (one) year after graduating, but in reality it is the same, namely one year of apprenticeship before graduating from the notary program and one year after graduating from the notary program. So it is actually the same as two years of apprenticeship, the only difference is the time it is carried out if the number of internships is long. Apprenticeship is only done for 1 (one) year after graduating, but in reality it is the same, namely one year of internship before graduating from the notary program and one year after graduating from the notary program. So it is actually the same as two years of apprenticeship, the only difference is the time it is carried out if the number of internships is long.

Starting from the two-year waiting period, association members require an internship at the Notary's office and association members feel that an internship is needed, while joint apprenticeship arises from filling that waiting period and the need for repetition or learning so that prospective notaries become a Notary Public professional. 
Implementation of internships for prospective notaries will at least review the lessons in lectures as well as lessons learned during internships at the notary's office.

During an apprenticeship at a notary office, for example, a prospective Notary only deals with making PT deeds, while others only make sale and purchase agreement deeds. Ordinary people who do internships at the notary's office do not actively participate, so their ability to make deeds is not optimal. The existence of a joint apprenticeship is like averaging what is learned together and reviewing the lessons learned during the lecture period. According to the Chairperson of the Indonesian Notary Association, joint apprenticeship which is linked to the practice of prospective notaries, this apprenticeship is arranged by the association, to provide one notary candidate

An obstacle that will occur to prospective notaries if they do not carry out an apprenticeship at the Notary's office so that they do not get a recommendation letter from the Notary who receives the internship, where the letter is used as a requirement to register as a joint apprentice participant. With a joint apprenticeship program, it is hoped that prospective notaries will deepen their mastery of increasing knowledge, insight into skills in making deeds. In addition, there are also criteria for Special Members to pay attention to their attitude and behavior as a Notary Public, as well as the attitude of integrity as a notary, understanding and control as a Notary.

Written in the attachment to the Association Regulation to become a Notary Public must first become an Extraordinary Member of the Indonesian Notary Association. In the Notary Appointment flow as contained in the attachment to the Regulation of the Association of the Indonesian Notary Association Number 10 of 2018, the first listed must pass from the Notary Masters, after graduating from the Notary Masters following the Special Member selection or commonly called pre-Special Members, after becoming an extraordinary member, then can do an internship. The apprenticeship in question is an internship in a notary office and a joint apprenticeship after the apprenticeship obtains an internship certificate, then ends with a code of ethics exam.

\section{CLOSING}

In fact, the effectiveness of the extension of the apprenticeship period is 12 (twelve) months to 24 (twenty four) months depending on the intention of the prospective notary who did the internship himself. Some notaries experience difficulties and 
experience confusion when opening an office even though they have undergone an apprenticeship period of 24 (twenty four) months, because they do not take advantage of time and do not carry out the apprenticeship activities properly. There are no internship implementation guidelines and there are no programs that must be undertaken during the internship, the effectiveness of the internship returns to each prospective notary who interns.

\section{REFERENCES}

Books:

Adjie, Habis. (2007). Hukum Notaris Indonesia Tafsir Tematik Terhadap UU No. 30 Tahun 2003 Tentang Jabatan Notaris, Cetakan Kedua, Bandung: Refika Aditama

Alwesius, Beberapa Catatan terhadap UUJN yang Baru, dalam http://alwesius.blogspot.com/2014/01/beberapa-catatanterhadap-uujn-yang-baru.html, p.1 accessed on1 March 2015

Hukum Online.com, Calon Notaris Wajib Magang Bersama, dalam http://www.hukumonline.com/berita/baca/calon-notaris-wajibmagang-bersama, accessed on 28 March 2015

Nazir, Mohammad. (1993). Metode Penelitian, Jakarta: Ghalia Indonesia

Thong Kie, Tan. (2007). Studi Notariat dan Serba-serbi Praktik Notaris, Cetakan Pertama, Jakarta, PT. Ichtiar Baru van Hoeve

Untung, Budi. (2001). Visi Global Notaris, Yogyakarta: Penerbit Andi

Interview:

Ammanah, Siti, Interview, Notary in Jepara Regency, January 12, 2021

Estu Prakoso, Mulung, Interview, Notary in Jepara Regency, September 19, 2018

Mulung Estu Prakoso, Interview, Notary in Jepara Regency, January 11, 2021

Debby Ekowati, Interview, Notary in Jepara Regency, January 13, 2021 